\title{
CITRA LESBIAN DALAM NOVEL INDONESIA AWAL TAHUN 2000-AN KARYA PEREMPUAN PENGARANG
}

\author{
Kasnadi \\ STKIP PGRI Ponorogo \\ email: kkasnadi@gmail.com
}

\begin{abstract}
Abstrak
Penelitian ini bertujuan mendeskripsikan identitas, interaksi, perjuangan, dan pandangan tokoh lain terhadap keberadaan tokoh lesbian dalam novel Indonesia awal tahun 2000-an karya perempuan pengarang. Penelitian ini merupakan penelitian deskriptif kualitatif. Pengumpulan data menggunakan teknik dokumentasi dengan strategi simak-catat. Analisis data menggunakan teknik analisis isi. Hasil penelitian sebagai berikut. Pertama, identitas tokoh lesbian (a) bertipe "butch", "femme", dan "andro", (b) lesbian bertipe "butch" berperilaku seperti laki-laki, (c) lesbian bertipe "femme" seperti perempuan, dan (d) lesbian bertipe "andro" bisa seperti laki-laki dan perempuan. Kedua, (a) interaksi tokoh lesbian dengan sesama lesbian dengan cara terang-terangan, dan (b) interaksi tokoh lesbian dengan keluarga dan masyarakat dengan cara sembunyi-sembunyi. Ketiga, tokoh lesbian berjuang untuk mempertahankan eksistensi kelesbianannya. Keempat, pandangan tokoh lain terhadap keberadaan tokoh lesbian ada yang positif dan ada yang negatif.
\end{abstract}

Kata kunci: citra lesbian, feminisme, novel Indonesia, perempuan pengarang

\section{LESBIAN IMAGES IN INDONESIAN NOVELS BY FEMALE WRITERS IN THE EARLY 2000'S}

\begin{abstract}
This study aims to describe lesbians' identity, interaction, struggle, and other figures' views of the existence of lesbian characters in Indonesian novels by female writers in the early 2000's. This was a qualitative descriptive study. The data were collected by the documentation technique using the reading-recording strategy. The data analysis used the content analysis technique. The results of the study are as follows. First, the identity of lesbian characters includes: (a) lesbians of "butch", "femme", and "andro" types; (b) lesbians of the "butch" type behaving like men; (c) lesbians of the "femme"type like women; and (d) lesbian of the "andro"type whocan be like men and women. Second, the interactions include: (a) the interaction of lesbian characters with fellow lesbians in an overt manner, and (b) the interaction of lesbian characters with family and society in a covert manner. Third, lesbian characters struggle to maintain their existence. Fourth, the views of other figures on the existence of lesbian characters are partly positive and partly negative.
\end{abstract}

Keywords: lesbian images, feminism, Indonesian novels, female writers

PENDAHULUAN

Wacana sastra Indonesia terus berkembang seiring dengan perjalanan waktu.
Dalam buku Angkatan 2000: Dalam Sastra Indonesia, angkatan yang baru muncul tersebut ditengarai dengan adanya wa- 
wasan estetika yang berbeda dengan angkatan sebelumnya (Rampan, 2000:xxv). Estetika baru itu, di satu sisi disuguhkan oleh para penulis muda yang berbakat yang didominasi oleh para perempuan dan di sisi lain gaya pengucapan terhadap tema-tema baru yang diangkatnya.

Menurut Faruk, gencarnya pembicaraan perempuan pengarang dalam sastra Indonesia modern tahun 2000-an itu, karena mereka (1) muncul pada saat terjadi krisis novel karya penulis laki-laki, (2) mengangkat sensibilitas yang lain, yakni mengangkat eksistensi wanita setara dengan laki-laki dalam berbagai aspek kehidupan dalam karya-karyanya, (3) menggambarkan seksualitas dan aktivitas seksual dalam karya-karyanya, dan (4) menjadi penulis masih sangat muda (2004: 119121). Menurut Herfanda (Republika, 5 Oktober 2003), ada tiga kemungkinan yang melatabelakangi lahirnya sastrawangi, yakni (1) penulis-penulis itu menganggap fiksi sekadar karya sastra yang tidak perlu dihubungkan dengan persoalan moral, (2) mereka muak pada norma lama yang mengungkung masyarakat dalam sikap "serba tabu" dan kebebasan kreatif, dan (3) mereka sengaja mengangkat "borok" dan "nanah" masyarakat urban untuk menohok kesadaran pembaca bahwa masyarakat Indonesia memang sudah "sakit parah". Oleh karena itu, perlu kesadaran bersama untuk menyelamatkannya. Pendapat yang senada dengan pendapat Herfanda adalah pada akhir dekade 1990an terjadi perubahan besar dalam ranah sosial, politik, dan kultural. Perubahan itu dimanfaatkan oleh perempuan pengarang Indonesia untuk melakukan penetrasi "moral" dan mengangkat tema seputar penderitaan wanita dan sekaligus kekuatan wanita (Anwar, 2009:201).

Gencarnya sambutan terhadap para perempuan pengarang tersebut, Damono menyebutnya dengan pernyataan di masa datang mungkin perkembangan sastra Indonesia akan ditentukan oleh perempuan
(2004:184). Hal senada diungkapkan oleh Ratna (2004:194) bahwa kelahiran perempuan pengarang ini mengindikasikan hadirnya kekuatan baru, kekuatan-kekuatan yang berfungsi sebagai antagonis, oposisi, bahkan sebagai antitesis terhadap tradisi sastra sebelumnya. Menurut St. Sunardi, dalam pengantar buku Sastra, Perempuan, Seks karya Katrin Bandel (2006:xi) fenomena munculnya perempuan pengarang butuh pengamatan kritis. Fenomena tersebut harus diakui sebagai babak baru sastra Indonesia. Seperti kata Richard Oh dalam pengantar buku Jangan Main-main (dengan kelaminmu), karya Djenar Maesa Ayu merupakan pembaharuan yang berarti dalam perkembangan sastra Indonesia saat ini (2004: xxvii).

Salah satu pembaharuan yang digencarkan para perempuan pengarang itu berkaitan dengan persoalan lesbian. Komunitas lesbian merupakan sebuah komunitas yang menarik untuk diperhatikan. Komunitas ini merupakan komunitas yang terpinggirkan dalam kehidupan bermasyarakat. Kebudayaan telah lama mencipta konstruk-konstruk yang memojokkan mereka dalam sudut kehidupan minoritas. Mereka tidak memunyai ruang bernafas yang bebas. Mereka terenggut keleluasaan dalam mewujudkan aktualisasi dirinya. Komunitas lesbian bagai hidup "bergerilya" di dalam terang atau hidup terang-terangan di dalam gelap (Chudori, 1999:121).

Kaum lesbian, merupakan kaum minoritas yang dipandang sebelah mata oleh banyak masyarakat, kelompok lesbian ini ingin mengaktualisasikan dirinya dalam kehidupan bermasyarakat. Sebagai pengarang, Linda Christanty menyatakan "saya mengungkap kehidupan kaum lesbian, bukan untuk tujuan erotis. Saya menggambarkan bahwa hubungan homoseksualitas itu indah, mengharukan dan tulus, sebagai cinta sejati. Selama ini orang beranggapan kalau jadi gay atau lesbian pasti untuk ngeseks saja. Anggapan itu 
merupakan anggapan yang sangat keliru (Laksmini, 2004:2007).

Kemunculan tema-tema lesbian itu merupakan gejala baru dari kelanjutan kritik feminis lesbian yang telah berkembang di Barat (Anwar, 2009:229). Para perempuan pengarang menulis novel bertema lesbian karena ingin mengangkat citra lesbian dari citra negatif menjadi positif. Fenomena lesbian menjadi sesuatu yang menarik karena wacana lesbian ini secara sosial belum dapat diterima secara umum oleh masyarakat Indonesia, baik dari segi agama maupun budaya. Oleh karena itu, wacana lesbian yang terekspresikan di dalam karya sastra penting didiskusikan.

Di Indonesia, perkembangan sastra bertema lesbian diawali dengan lahirnya novel Relung-relung Hati Sisi (1983) karya Mira W., Menguak Duniaku: Kisah Sejati Transeksual (1998) karya Ramadhan K.H. Sejak kedua novel itu lahir, bermunculanlah karya-karya bertema lesbian. Misalnya: Lines: Kumpulan Cerita Perempuan di Garis Pinggir karya Ratri M., Larung (2001) karya Ayu Utami, Garis Tepi Seorang Lesbian (2003) karya Herlinatiens, Miss Lu (2003) karya Naning Pranoto, Bukan Saya Tapi Mereka Yang Gila (2004) karya Stepani Hid, Jangan Beri Aku Narkoba (2004) karya Alberthiene Endah, Tabularasa (2004) karya Ratih Kumala, Di Cintai Jo (2005) karya Alberthiene Endah, Nayla (2005) karya Djenar Maesa Ayu, Rahasia Bulan (kumpulan Cerpen, 2006) karya Is Mujiarso (Ed), Dimsum Terakhir (2006) dan Gerhana Kembar (2007) karya Clara Ng, dan (5) Kembang Kertas (2007) karya Eni Martini.

\section{METODE}

Desain yang digunakan dalam penelitian ini adalah deskripsi kualitatif. Teknik pengumpulan data menggunakan teknik baca-simak-catat. Sumber data penelitian ini adalah (1) Larung (2001) karya Ayu Utami, (2) Garis Tepi Seorang Lesbian karya Herlinatiens (3) Nayla (2005) karya Djenar Maesa Ayu, (4) Dimsum Terakhir (2006) karya Clara Ng., (5) Gerhana Kembar (2007) karya Clara Ng., dan (6) Kembang Kertas (Ijinkan Aku Menjadi Seorang Lesbian) (2007) karya Eni Martini. Teknik dan prosedur analisis data menggunakan teknik analisis isi dan prosedur analisis data menggunakan metode ala Miles dan Huberman, yakni reduksi data, penyajian data, dan penarikan kesimpulan secara terus-menerus dan berkelindan untuk menemukan citra lesbian dalam novel Indonesia awal tahun 2000-an karya perempuan pengarang tersebut. Teknik pengujian keabsahan penelitian menggunakan trianggulasi. Trianggulasi teori, metode, dan data melalui diskusi, seminar, dan konsulatasi kepada pakar.

\section{HASIL DAN PEMBAHASAN}

Berdasarkan hasil analisis data ditemukan empat aspek sebagai penanda citra tokoh lesbian dalam novel Indonesia awal tahun 2000-an karya perempuan pengarang. Keempat aspek itu merupakan penjabaran dari fokus dan pembuktian tujuan penelitian. Keempat aspek yang mengakumulasi pada citra lesbian tersebut mencakup (1) identitas tokoh lesbian, (2) interaksi tokoh lesbian, (3) perjuangan tokoh lesbian dalam memertahankan eksistensi kelesbianannya, dan (4) pandangan tokoh lain terhadap keberadaan tokoh lesbian.

\section{Identitas Tokoh Lesbian}

Menurut Devi Citra Yanti, identitas lesbian dipengaruhi oleh pola asuh orang tuanya. Pola asuh tersebut akan berpengarah pada orientasi kehidupan masa depan kaum lesbian (2016:791). Identitas lesbian dapat dilihat dari berbagai aspek. Aspek yang dapat dijadikan paradigma seorang lesbian mencakup (a) tipe seorang tokoh lesbian, (b) nama yang dipilih tokoh lesbian, (c) bentuk tubuh seorang lesbian, (d) cara berpakain seorang lesbian, (e)

Citra Lesbian dalam Novel Indonesia Awal Tahun 2000-an Karya Perempuan Pengarang 
ucapan, pikiran, dan perilaku seorang lesbian, dan (f) pekerjaan seorang lesbian.

Tipe tokoh lesbian terbagi menjadi (a) "butche", (b) "femme", dan (c) "andro". "Butche" adalah lesbian yang berperan sebagai laki-laki. Oleh karenanya, nama, tubuh, pakaian, ucapan, pikiran, perilaku, dan pekerjaan mereka layaknya seorang laki-laki. "Femme' adalah lesbian yang berperan sebagai perempuan. Nama, tubuh, pakaian, ucapan, pikiran, perilaku, dan pekerjaan mereka layaknya seorang perempuan. "Andro" lesbian yang bisa berganti-ganti peran, bisa berperan sebagai laki-laki dan bisa berperan sebagai perempuan. Nama, tubuh, pakaian, ucapan, pikiran, perilaku, dan pekerjaan mereka seperti laki-laki dan atau perempuan.

Henrietta (Henri) dalam Gerhana Kembar, Juli dalam Nayla, Juliet (Juli) dalam Kembang Kertas, Rosi dalam Dimsum Terakhir, Shakuntala dalam Larung adalah sosok-sosok "butche". Nama, bentuk tubuh, potongan rambut, cara berpakaian, ucapan, perilaku, dan pekerjaannya seperti yang dilakukan oleh kaum lakilaki. Mereka suka berpenampilan tomboy, otot kekar, rambut cepak, celana jins, sepatu kets, suka merokok, dan suka ugal-ugalan dalam mengendarai motor. Mereka melakukan pekerjaan yang layak dilakukan oleh laki-laki. Henrietta sebagai seorang pramugari, mengecat tembok, Rosi sebagai petani bunga, Juli sebagai pengatur lampu di tempat diskotik.

Apa yang dilakukan Henrietta, Rosi, dan Juli selaras dengan konsep feminis liberal yakni perempuan harus mampu sejajar dengan laki-laki. Hal ini sesuai dengan pendapat Wiyatmi atas kajian novel Burung-burung Rantau karya Y.B. Mangunwijaya, Canting karya Artswendo Atmowiloto, dan Putri karya Putu Wijaya. Ia menyatakan bahwa peran perempuan dalam ketiga novel tersebut tidak sematamata hanya mengatur rumah tangga, tetapi juga berperan di masyarakat, ter- masuk dalam bidang ekonomi. Dalam perspektif feminis gambaran tersebut menunjukkan adanya perlawanan terhadap kuasa patriarkat yang membatasi partisipasi perempuan di sektor publik, serta belenggu kebebasan perempuan dalam menjalani kehidupan dan perannya di sector domestik maupun publik dalam novel-novel Indonesia yang dikaji (2013:128).

Lebih dari itu, dengan orientasi seks mereka yang hanya untuk sesama jenis menunjukkan adanya konsep feminis radikal. Mereka mampu meniadakan keberadaan laki-laki dalam kehidupannya. Dengan orientasi seks sesama jenis menunjukkankan bahwa kaum lesbian tidak membutuhkan laki-laki dalam mendapatkan kesenangan seks. Gambaran femonena seks dalam novel-novel karya pengarang perempuan memiliki hubungan dengan pandangan aliran feminisme yang melatarbelakanginya. Pandangan feminisme radikal tampak pada novel Sm, Larung, Tabularasa, Garis Tepi Seorang Lesbian, WSV, sementara pandangan feminisme liberal pada novel MahadewaMahadewi, Ip, JJ, Saman, dan Dadaisme (Wiyatmi, 2012:152).

Fola Damayanti dalam Gerhana Kembar, Kartini dalam Kembang Kertas, Dharma dalam Dimsum Terakhir, Laila dalam Larung adalah tokoh lesbian yang berperan sebagai perempuan ("femme"). Mereka layaknya sebagai perempuan, lemah lembut, kulit halus, berpenampilan feminin, dan pekerjaannya pun seperti layaknya pekerjaan perempuan, seperti guru dan ibu rumah tangga. Orientasi seks mereka di samping mencintai perempuan juga mencintai laki-laki.

Dari tokoh lesbian yang terdapat dalam novel Indonesia awal tahun 2000-an karya perempuan pengarang, sosok Ashmora Paria dalam Garis Tepi Seorang Lesbian dan Nayla dalam Nayla adalah tokoh yang berperan sebagai "andro". Mereka dapat berperan sebagai laki-laki dan juga 
sebagai perempuan. Pada saat tertentu mereka dapat lemah lembut, tetapi pada saat yang lain mereka bisa berpenampilan seperti laki-laki yang kuat dan kasar. Mereka feminin sekaligus maskulin.

Rosi, tokoh utama dalam Dimsum Terakhir, merasakan identitasnya seperti mata uang yang mempunyai dua sisi sama penting. Setiap saat, kegamangan akan muncul dalam diri Rosi. Ia mencari jatidiri melalui citraan yang tercermin dalam dirinya, sehingga muncul citraan dirinya sebagai cermin untuk melihat diri yang asli. Kegamangan itu akhirnya ditemukan dengan perasaan nyaman dan menikmati sebagai sosok yang asli, yakni laki-laki yang tumbuh dan berkembang dalam tubuh perempuan. Masyarakat umum melihat sosok Rosi sebagai perempuan aneh, karena Rosi selalu berpenampilan layaknya seorang laki-laki, seperti tampak pada kutipan di bawah ini.

Rosi menikmati masa-masa remajanya yang sangat gamang dengan pencarian identitas diri. Perlahan-lahan, $\mathrm{BH}$ tidak pernah lagi dia kenakan. Memakai BH sangat tidak nyaman. Tentu saja sembunyi-sembunyi, jika ketahuan, Mama pasti marah besar. Membebat dada dengan kain mulai dilakukannya ketika dia berusia tujuh belas tahun. Rambutnya yang selalu pendek dipangkas semakin pendek. Gaya tentara, cepak habis. Bukan sekedar gaya rambut pendek-tapi-feminin. Sepatunya selalu sepatu olah raga berwarna coklat karena terlalu kotor. Rosi tidak pernah berbedak, jarang pula menyisir. Dia hanya menggunakan jemarinya untuk merapikan rambut (DT, 2006:181).

Kelelakian Rosi terlihat jelas dalam bungkus penampilan dan perilakunya. Salah satu pakaian perempuan modern Indonesia, yakni "buste houder" (BH) tidak disukai. $\mathrm{BH}$, sebagai pemegang buah dada dan salah satu simbol keperempuanan, dihindari karena tidak nyaman dan merepotkan. Potongan ramput cepak, sebagai ciri khas yang dimiliki laki-laki modern Indonesia, malah ia sukai karena tidak perlu mengurus dengan menyisir rapi layaknya perempuan. Untuk melengkapi gaya laki-laki, ia selalu memakai sepatu kets biar tampak maskulin bahkan "macho". Dikenakannya semua atribut lakilaki dan dihindarinya atribut perempuan itu tidak lain adalah panggilan nurani Rosi yang paling dalam.

Dorongan dari dalam jiwa Rosi untuk mengaktualisasi kediriannya terlihat sangat kuat. Dorongan itu tercermin dalam pertemanan, pergaulan, dan perilaku sehari-hari. Rosi menunjukkan identitas diri sebagai seorang lelaki. Ia lebih sering dan suka bergaul dengan teman laki-laki. Dalam kesehariannya, ia lebih menikmati bersama teman laki-laki bila dibandingkan dengan teman perempuan. Pergaulan dan perilaku merupakan akses Rosi sebagai wujud pengakuan masyarakat terhadap keberadaannya. Keinginan untuk melakukan sesuatu demi memenuhi kata hati seperti kesenangan (pleasure) merupakan pilihan hidup Rosi. Dalam pandangan Freud, apa yang dilakukan Rosi masuk dalam tataran $i d$, sebuah prinsip untuk memenuhi kebutuhan yang dibawa sejak lahir. Pencarian Rosi akan identitas dirinya semakin jelas. Ia semakin menemukan dan memilih sebagai sosok laki-laki.

Keenam aspek tersebut menyatu pada karakterisasi sebagai identitas tokoh lesbian dalam novel Indonesia awal tahun 2000-an karya perempuan pengarang. Oleh karena itu, lesbian adalah sosok yang memunyai identitas tersendiri yang berbeda dengan masyarakat umum. Identitas yang mencolok adalah orientasi seks yang ditujukan kepada sesama jenis. Identitas diri lesbian menurut Devi Citra Yanti (2016: 792) dipengaruhi oleh lingkungan, baik lingkungan keuarga maupun lingkungan masyarakat luas. Berkaitan 
dengan lingkungan keluarga, pola asuh orang tua sangat berpengaruh terhadap orientasi masa depan seorang lesbian.

\section{Interaksi Tokoh Lesbian}

Para tokoh lesbian dalam novel Indonesia awal tahun 2000-an yang ditulis perempuan pengarang sebagaimana halnya manusia pada umumnya. Mereka juga membutuhkan hubungan dengan tokoh lain. Mereka mengingkan interaksi karena mereka juga merupakan makhluk sosial. Interaksi yang dibangun untuk mengaktualisasikan diri di masyarakat. Interaksi yang dilakukuan oleh para tokoh lesbian tersebut mencakup (1) interaksi sesama tokoh lesbian, (2) interaksi tokoh lesbian dengan keluarga, dan (3) interaksi tokoh lesbian dengan masyarakat.

Interaksi dengan sesama lesbian dijadikan alat untuk bertukar pikiran dan menjalin hubungan seksual. Mereka membangun komunitas tersendiri, komunitas sesama lesbian. Komunitas tersebut dijadikan sebagai wadah untuk mengaktualisasikan diri baik di dalam lingkungannya sendiri maupun di lingkungan masyarakat luas. Komunitas lesbian menjadi wadah penting untuk mengutarakan keluh kesahnya menjadi seorang lesbian. Mereka di dalam komunitasnya bisa dengan leluasa mengejowantahkan jati diri yang sesungguhnya. Berkaitan dengan komunitas lesbian ini, hasil kajian Christiany Juditha (2014:30) terhadap realitas lesbian, gay, biseksual, dan transgender (LGBT) dalam majalah menunjukkan dengan majalah tergambar bahwa kaum minoritas seperti LGBT semakin mengukuhkan keberadaan mereka meski banyak mendapat tentangan. Justru melalui media ini, kaum LGBT dapat dengan bebas mengekspresikan diri dan identitas gender mereka sekaligus memberikan pengaruh bagi pembacanya.

Di samping tokoh-tokoh lesbian dalam novel Indonesia awal tahun 2000-an itu membentuk komunitas sebagai media untuk berkomunikasi dengan sesama jenis, mereka juga tidak bisa lepas dari kehidupan keluarga dan masyarakat luas. Mereka juga berinteraksi dengan keluarga dan masyarakat umum. Interaksi dengan keluarga dan masyarakat luas dijadikan media untuk menunjukkan dan memperjuangkan eksistensi kelesbianannya agar diketahui, dipahami, dan dimaklumi keberadaannya. Komunikasi tokoh lesbian dengan keluarga dan masyarakat luas dilakukan dengan cara sembunyisembunyi. Hal ini, karena kelesbianan mereka belum bisa diterima baik oleh keluarga maupun masyarakat luas.

Dalam komunitas lesbian nampak adanya dorongan kuat untuk menjaga rahasia hubungan sesama jenis serta tidak mengumbar privasi mereka ke orang di luar komunitas mereka dan ingin tetap menjaga keintiman hubungan mereka tanpa diketahui orang lain (Wahyudi dan Widhiasih, 2016:45). Oleh karena itu, interaksi yang mereka lakukan, baik dengan sesama lesbian maupun dengan keluarga dan masyarakat adalah untuk membangun komunikasi secara baik dan wajar agar keberadaannya berterima di masyarakat. Jika hal itu dapat dicapai mereka akan dapat hidup nyaman dan aman.

\section{Perjuangan Tokoh Lesbian}

Keberadaan tokoh lesbian dalam novel Indonesia awal tahun 2000-an yang ditulis oleh perempuan pengarang belum diterima oleh masyarakat. Untuk itu mereka berjuang untuk mendapatkan keberterimaannya. Dalam kehidupan kesehariannya lesbian secara terus-menerus ditindas kaum laki-laki. Sistem patriarki menguasai kehidupan mereka. Mereka merasa tidak dapat bernafas dengan bebas karena adanya kungkungan budaya patriarki yang masih kuat. Penindasan kaum heteroseksual terhadap kaum lesbian memunculkan pemikiran dan sikap kaum lesbian. Pemikiran dan sikap itu menjadi 
embrio perjuangan mereka untuk memertahankan eksistensi kelesbianannya.

Perjuangan tokoh lesbian dalam memertahankan kelesbianannya di dalam novel Indonesia awal tahun 2000-an karya perempuan pengarang ini meliputi (1) aspek yang diperjuang, (2) pola perjuangan, (3) konflik dan solusi yang dihadapi dalam perjuangan, dan (4) tujuan perjuangan.

Aspek yang diperjuangkan tokoh lesbian adalah nilai-nilai kemanusiaan. Mereka berjuang menuntut kesetaraan gender, mendaptkan hak asasinya, dan menghendaki berterima orientasi seksnya. Mereka menghendaki adanya kesetaraan dalam berbagai aspek kehidupan dengan tokoh laki-laki dan tokoh perempuan heteroseks. Mereka menginginkan hak asasinya sebagai manusia pada umumnya. Hal ini sesuai dengan pendapat Muqoyyidin, (2013:509) bahwa feminis muslim Amina Wadud menonjolkan semangat egalitarianisme. Ia menginginkan suatu keadilan dan kerja sama antara kedua jenis kelamin tidak hanya pada tataran makro (negara, masyarakat), tetapi juga sampai ke tingkat mikro (keluarga).

Dalam mewujudkan harapan dan keinginannya itu, mereka berjuang dengan cara sembunyi-sembunyi dan terangterangan. Pada awalnya, tokoh-tokoh lesbian itu belum berani menampakkan diri secara terbuka di masyarakat. Mereka lebih memilih perjuangan dengan cara yang terselubung. Dalam perkembangannya, pola perjuangan mereka berubah menjadi terbuka, karena adanya panggilan jiwa yang paling dalam dan dipicu oleh desakan masyarakat yang selalu memojokkan keberadaan mereka.

Dalam perjuangannya tokoh lesbian mendapatkan hambatan baik dari kalangan keluarga maupun masyarakat umum. Hambatan tersebut dapat diselesaikan melalui ceramah, diskusi, dan perlawanan. Dalam posisi yang terpojok, mereka meninggalkan Indonesia pergi ke negara Barat, karena di sana mereka mendapat- kan tempat yang nyaman dan damai bagi kehidupannya.

Tujuan perjuangan kaum lesbian sebenarnya adalah untuk menuntut keadilan dan menegakkan kebenaran. Mereka lahir tidak meminta dan memohon menjadi seorang lesbian. Kehadiran mereka di dunia ini adalah kehendak Tuhan Yang Mahakuasa.

Paria memperjuangkan diri dan kaumnya atas penindasan kaum heteroseksual tampak jelas pada kutipan data di bawah ini.

Aku perempuan di garis tepi yang ingin menebalkan atmosfer berpikir yang lebih madani. Meski sulit, aku masih terus mencoba menepi untuk mencoba memberikan kesempatan bagi orang lain berpikir, bahwa kami ada. Dan kami ada karena kami memang diciptakan untuk ada. Bahwa kami ada bukan untuk ditindas dengan segala keburukan dan ketidakadilan (GTSL, 2003:88).

Dari kutipan data di atas dapat dipahami bahwa sosok Ashmora Paria menginginkan masyarakat mau menggunakan pemikirannya. Paria menghendaki masyarakat juga melihat bahwa keberadaan lesbian di masyarakat itu tidak dapat dipungkiri. Paria, sebagai lesbian, ingin eksistensinya diterima oleh masyarakat. Hal ini, Paria sadar bahwa kehadirannya di dunia ini bukan karena permintaannya, tetapi karena kemauan Yang Mahakuasa. Sebagai seorang lesbian, kehidupan Paria dimanfaatkan untuk memperjuangakan hak-hak kaumnya sebagai manusia. Apa yang dilakukan Paria, seperti ungkapan pengarangnya, yakni Herlinatiens. Ketika diwawancarai peneliti, Herlinatiens, sebagai pengarang novel Garis Tepi Seorang Lesbian, mengungkapkan bahwa dirinya ingin diterima oleh masyarakat bukan karena ia jenis kelaminnya, yakni perempuan, tetapi karena sebagai manusia yang seutuhnya ${ }^{1}$. Oleh karena itu, kata 
Herlinatiens perempuan, termasuk juga lesbian, adalah manusia yang wajib dihormati dan dihargai. Bagi Herlinatiens, rasa kemanusiaan lebih penting daripada gender, keturunan, warna kulit, suku, jenis kelamin, orientasi seks, kedudukan, dan status sosial dalam kehidupan bermasyarakat.

Persoalan kemanusiaan tidak mengutamakan identitas, akan tetapi mementingkan humanitas. Persoalan kemanusiaan yang diperjuangkan oleh Paria merupakan perjuangan membela ketidakadilan terhadap kaum lesbian. Menurut Hun, dalam Kasnadi (2017:36), as humanity thingking presented by Pramoedya in Human Earth tetralogy. The problem of humanity is derived from the assumption that man life his as a human being is intrinsically to break away from all the shackles, for example, the rejection of conservative cultural heritage, resistance against the injustice of colonial rule, or the spirit of building freedom and human welfare within the scope of national unity.

\section{Pandangan Tokoh Lain terhadap Ke- beradaan Tokoh Lesbian}

Tokoh lesbian merupakan bagian dari anggota masyarakat di mana mereka hidup. Dalam pergaulan sehari-hari mereka mendapatkan sorotan dari berbagai kalangan. Tokoh-tokoh lain yang memerhatikan keberadaan tokoh lesbian dalam novel Indonesia awal tahun 2000an karya perempuan pengarang berasal dari (1) kalangan keluarga, (2) kalangan intelektual, dan (3) kalangan masyarakat umum.

Tokoh-tokoh, baik yang berasal dari kalangan keluarga lesbian sendiri, kalangan intelektual, dan masyarakat umum ada yang mendukung apa yang dilakukan tokoh lesbian dan ada yang menolaknya. Mereka yang mendukung perpandangan bahwa setiap manusia dilahirkan dengan jati dirinya masing-masing. Mereka memunyai kebebasan untuk memilih jalan hidup yang dikehendakinya. Toh, mereka lahir tidak meminta tetapi sudah digariskan dari Sang Pencipta.

Dukungan keluarga terlihat pada perilaku Lendy terhadap neneknya yang lesbian dalam Gerhana Kembar. Pemahaman terhadap keberadaan neneknya menjadikan Lendy sebagai tokoh yang lebih moderat. Ia merasa kasihan dan iba terhadap kegalaun yang selama hidup menimpa neneknya. Inilah dialog Lendy dan Ibunya (Eliza) yang menunjukkan sikap empati yang dalam terhadap neneknya (Diana) yang lesbian. "Kasihan Oma." "Kasihan?" Ekspresi wajah Eliza berubah lagi. "Mengapa mengatakan kasihan untuk cinta sesama jenis yang jelas-jelas bertentangan dengan agama dan Tuhan?" (GK, 2007:237).

Lendy, sebagai cucu, tidak saja memahami apa yang dirasakan neneknya, tetapi ia juga menerima dengan penuh pengertian terhadap keberadaan neneknya. Meskipun agama melarang persoalan cinta sejenis, Lendy tetap melihat bahwa persoalan cinta adalah persoalan pribadi seseorang. Cinta adalah cinta. Tidak pada tempatnya jika orang lain masuk dalam urusan hak asasi yang paling asasi itu. "Saya pikir...," kata Lendy hati-hati. Pipinya merah padam. "Cinta adalah cinta. Dia tidak mengenal jenis kelamin." (GK, 2007:237). Fenomena tersebut dilandasi oleh pandangan feminisme radikal dan liberal yang ditandai dengan menentang patriarkat dan kekerasan seksual, menganjurkan lesbianisme, dan menuntut persamaan hak antara perempuan dengan laki-laki, termasuk dalam hubungannya dengan persoalan seksualitas (Wiyatmi, 2012:153).

Dari sisi humanisme, terlihat jelas bahwa Lendy adalah manusia yang berjiwa besar. Ia membela orang yang tertindas dari kehidupan masyarakat. Lesbian merupakan wacana yang aneh dan ganjil di mata masyarakat. Orang-orang lesbian dianggap pribadi yang menyimpang, pribadi yang tidak normal. Karena itu, 
mereka hidup dalam keresahan, kegalauan, dan ketidaknyamanan. Melihat realitas kaum lesbian seperti itu Lendy tampil sebagai pembela.

Tindakan itu dilakukan Lendy setelah menemukan naskah di almari neneknya (Diana). Lendy bersikukuh untuk mencari Henrietta (Selina) yang telah hilang dari hadapan Diana. Lendy sangat berambisi untuk merajut kembali cerita masa silam yang dialami keluarganya. Lendy berupaya keras untuk menyatukan peristiwa aneh yang dialami neneknya. Lendy mengambil sikap harus menemukan Selina dan menyatukan dengan Diana. Ketika ditanya ibunya "Apa yang akan kita lakukan?" Jawab Lendy dengan singkat "Mempertemukan Oma dengan Tante Selina..." (GK, 2007:256). Upaya Lendy untuk mempertemukan Diana dengan Selina dapat dilihat pada kutipan di bawah ini.

Kata Prity dia sedang mencari nenek yang hilang. Tapi Lendy menemukan satu kenyataan baru. Bukan sekadar mencari nenek yang hilang. Lebih daripada itu. Lendy sedang merangkai masa lalu yang tercerai-berai. Masa lalu keluarganya. Menjadi satu keping yang utuh (GK, 2007: 265).

Di samping tokoh lain yang mendukung keberadaan lesbian, juga terdapat tokoh lain yang menolak keberadaan lesbian. Tokoh lain yang menentang dan menolak pemikiran dan perilaku tokoh lesbian beranggapan bahwa lesbian itu tabu, menjijikkan, dan dosa. Masyarakat memunyai adat-istiadat, aturan, budaya yang harus diikuti dan dipatuhi oleh seluruh anggota masyarakat. Lesbian juga merupakan bagian dari lingkungan masyarakatnya. Mereka hidup tidak sendirian, tetapi bersama masyarakat luas. Di samping itu perilaku lesbian merupakan perilaku dosa. Perilaku tokoh lesbian adalah perilaku yang menyimpang dari ajaran agama.
Tokoh yang menolak ini ada yang berasal dari anggota keluarga dan juga tokoh dari luar keluarga. Mereka mempunyai pandangan kaum lesbian merupakan kelompok yang patut untuk dijauhi dari kehidupan masyarakat. Mereka meminggirkan kaum lesbian dari kehidupan masyarakat.

Keluarga besar Paria tidak suka terhadap keberadaan Paria sebagai lesbian. Lesbian dianggap menjadi aib dalam keluarga besar Paria. Pengakuan Paria, keluarganya membuang jauh lepas dari pertalian keluarga (GTSL, 2003:11). Herlinatiens, sebagai pengarang, melukiskan ketidakcocokan keluarga besar Paria terhadap keberadaan kaum lesbian lewat pengakuan tokoh Paria terhadap Gita seperti tampak pada kutipan "Gita, ibuku masih terus melancarkan aksi perang denganku, bapakku hanya diam, dia lelaki yang manut sama istri, kau ingat bukan?" (GTSL, 2003:30). Gaya pengucapan Herlinatiens lewat iner dialog tokoh Paria dalam data ini "Selama ini aku tidak pernah merasa beruntung telah mempunyai ibu seperti dia. Perempuan ningrat yang kolot dan keras" (GTSL, 2003:68).

Pernyataan di atas mengindikasikan bahwa ibunya jelas-jelas tidak setuju atas pilihan hidupnya. Paria merasa hidupnya tertekan, penuh aturan, dan kungkungan dari seorang ibu yang berpaham tradisional. Pantaslah jika ibunya semakin jauh dari dirinya. Meskipun demikian, Paria tetap teguh pada pendiriannya, sebagai seorang lesbian tetap memperjuangkan kelesbianannya, seperti konsep feminis radikal yang mengesahkan hubungan sejenis.

Tidak saja ibunya yang membenci Paria sebagai lesbian, tetapi semua keluarga besarnya. Ucapan Paria pada data di bawah ini secara eksplisit menyayangkan dirinya menjadi orang yang keluar dari rambu-rambu keluarga. "Sidang keluarga pun digelar di rumah simbah. Aku kembali menjadi bahan pembicaraan. 
Tentang seorang keponakan yang tidak normal. Tentang seorang keponakan yang harus segera dikawinkan, entah dengan siapapun" (GTSL, 2003: 80). Pernyataan tokoh Paria itu didukung ucapan Pakdhe di bawah ini.

"Itu dosa nduk! Dilarang Tuhan. Ini aib keluarga, jangan sampai orang luar tahu. Kamu ini ponakan pakdhe yang cantik bukan? Masih to? Dulu pakdhe sering membelikan baju untukmu, nah sekarang kamu pingin opo? Nanti pakdhe belikan. Kamu turunan orang baik-baik nduk. Meski namamu Paria. Kamu bukan turunan sudra. Kamu orang ningrat. Nggak pantas berbuat nyleneh (GTSL, 2003: 81).

Ketika bapak Paria mencoba untuk memecah kesunyian dalam sidang keluarga, secara spontan ibu marah-marah. Pakdhe sangat menyayangkan pemikiran bapak, dan simbah merespon dengan tindakan yang menolak. "Bapak berkata tegas dalam kehalusan kata-katanya. Ibuku spontan marah-marah. Dan pakdhe "Wah ketiwasan, bagaimana sampeyan ini dik." Simbah dengan sangat marah segera masuk ke dalam kamarnya, dan mengunci pintunya dari dalam, membuat orang lain bingung dan resah" (GTSL, 2003:83).

Sikap dan pandangan tokoh lain terhadap keberadaan tokoh lesbian ada yang pro dan ada yang kontra. Mereka yang berpandangan pro bersikap menerima keberadaan dan kehadirannya. Mereka yang berpandangan kontra terhadap keberadaan lesbian bersikap menolaknya. Tokoh lain, baik dari kalangan keluarga, kalangan intelektual, maupun kalangan masyarakat umum ada yang menerima dan ada yang menolak keberadaan mereka. Oleh karenanya, eksistensi kaum lesbian menjadi sebuah diskusi yang menarik di mata masyarakat. Eksistensi lesbian tersebut sejalan dengan pemikiran teori feminis baik feminis liberal maupun radikal.

\section{SIMPULAN}

Berdasarkan hasil penelitian, penelitian ini dapat disimpulkan bahwa citra lesbian dalam novel Indonesia awal tahun 2000-an karya perempuan pengarang adalah sebagai berikut.

Pertama, lesbian adalah sosok yang memunyai identitas tersendiri. Identitas tersebut dapat dilihat dari tipe, nama, pekerjaan, pemikiran, dan penampilannya. Identitas yang mencolok adalah orientasi seks yang ditujukan kepada sesama jenis. Identitas itu menjadikan lesbian memunyai penampilan yang berbeda dengan masyarakat pada umumnya.

Kedua, kaum lesbian memunyai komunitas tersendiri. Interaksi yang dilakukan kaum lesbian dalam komunitasnya melahirkan pemikiran, konsep, dan tindakan melahirkan sikap untuk mengaktualisasikan diri di masyarakat.

Ketiga, penindasan sistem patriarki terhadap kaum lesbian mendorong kaum lesbian menentukan sikap. Sikap kaum lesbian menjadi embrio perjuangan menuntut hak asasinya. Hak asasi yang diperjuangkan kaum lesbian terkait dengan kesetaraan jender, kebebasan orientasi seks, dan pengakuan keberadaannya. Oleh kareana itu, kaum lesbian berjuang menuntut keadilan dan menegakkan kebenaran.

Keempat, eksistensi lesbian menjadi sebuah dialektika di masyarakat. Terdapat dua konsep dalam memandang keberadaan lesibian. Sebagian masyarakat pro dan sebagian kontra terhadap keberadaan lesbian. Masyarakat yang pro menerima keberadaan lesbian, sedangkan masyarakat yang kontra menolak kehadiran lesbian.

\section{UCAPAN TERIMA KASIH}

Artikel ini disarikan dari disertasi yang berjudul "Citra Lesbian dalam Novel Indonesia Awal Tahun 2000-an Karya Perempuan Pengarang (Kajian Feminsme)". Oleh karena itu, peneliti 
ucapkan terima kasih kepada Prof. Dr. Budi Darma, M.A. selaku promotor dan Prof. Dr. Haris Supratna, M.Pd. selaku kopromotor. Di samping itu diucapkan terima kasih kepada semua pihak yang membatu terwujudnya disertasi ini.

\section{DAFTAR PUSTAKA}

Anwar, Ahyar. 2009. Genealogi Feminis. Jakarta: Penerbit Republika.

Ayu, Djenar Maesa. 2004. Jangan Mainmain (dengan kelaminmu). Jakarta: PT Gramedia Pustaka Utama.

Ayu, Djenar Maesa. 2005. Nayla. Jakarta: PT Gramedia Pustaka Utama.

Bandel, Katrin. 2006. Sastra, Perempuan, Seks. Yogyakarta \& Bandung: Jalasutra.

Chudori, Laila S. 1999."Gay dan Lesbian dalam Soluloid" dalam Utan Kayu Buku Kedua Bertandang dalam Proses (Ahmad Sahal (Peny). Jakarta: Yayasan Kalam.

Damono, Sapardi Djoko. 2004. “Meninjau Perempuan dalam Sastra" Jurnal Prosa. No.4. 2004.

Faruk. 2004. "Novelis Wanita dan Budaya Populer". Jurnal Prosa, No 4, 2004.

Herfanda, Ahmadun Yosi. 2003. "Fiksi dan Masalah Keyakinan Estetik", Republika, Minggu, 5 Oktober 2003, hlm. 8.

Herlinatiens. 2003. Garis Tepi Seorang Lesbian. Yogyakarta: Galang Press.

Juditha, Christiany. 2014. "Realitas Lesbian, Gay, Biseksual, dan Transgender (LGBT) dalam Majalah". Dalam jurnal Komunikasi, Volome 6, Nomor 3, 2014, hlm.22-30.

Kasnadi. 2017. "The Strugle of a Lesbian in the Novel Garis Tepi Seorang Lesbian (GTLS) by Herlinatiens". Dalam jurnal IMPACT: International Journal of Reshearch in Humanities, Arts and Literature (IMPACT: IJRHAL). Vol. 5, Issue 1, Januari 2017, Hlm. 31-38.

Laksmini, Gita Widya. 2004. "Seks, Sastra, dan Perempuan" Jurnal PROSA. Jakarta: PT Metafor Intermedia Indonesia.
Martini, Eni. 2007. Kembang Kertas (Ijinkan Aku Menjadi Lesbian). Jakarta: Trust Publishing.

Muqoyyidin, Andik Wahyun. 2013. “Wacana Kesetaraan Gender: Pemikiran Islam Kontemporer tentang Gerakan Feminisme Islam". Dalam jurnal $\mathrm{Al}$ Ulum, Volume 13, Nomor 2, Desember 2013, Hlm. 491-512.

Ng., Clara. 2006. Dimsum Terakhir. Jakarta: Gramedia Pustaka Utama.

Ng., Clara. 2007. Gerhana Kembar. Jakarta: Gramedia Pustaka Utama.

Rampan, Korie Layun. 2000. Angkatan 2000: Dalam Sastra Indonesia. Jakarta: Gramedia.

Ratna, Nyoman Kutha. 2004. Teori, Metode, dan Teknik Penelitian Sastra dari Strukturalisme Hingga Postrukturalisme Perspektif Wacana Naratif. Yogyakarta: Pustaka Pelajar.

Utami, Ayu. 2001. Larung. Jakarta: Kepustakaan Populer Gramedia.

Wahyudi, Nyoman Deni dan Luh Ketut Sri Widhiasih. 2016. "Representasi Lesbian, Gay, dan Transgender dalam Antologi Cerpen Penjara: Sebuah Tinjauan Sosiopragmatik". Dalam Jurnal Ilmiah Pendididikan, Volume 2, Nomor 1, 2016, hlm. 38-49.

Wiyatmi. 2012. Kritik Karya Feminis: Teori dan Aplikasinya dalam Sastra Indonesia. Yogyakarta: Penerbit Ombak.

Wiyatmi. 2013. Menjadi Perempuan Terdidik: Novel Indonesia dan Feminisme. Yogyakarta: UNY Press.

Yanti, Devi Citra. 2016. “Identitas Diri dan Orientasi Masa Depan Kaum Lesbian di Samarinda". Dalam jurnal Psikoborneo, Vol. 4, No. 4, 2016, hlm. 784-792.

\section{Footnotes}

1 Wawancara dengan Herlinatiens melalui surat elektronik pada 31 Mei 2012 